\title{
Genetic hearing loss: a study of 228 Brazilian patients
}

\author{
Silvia Bragagnolo Longhitano and Décio Brunoni
}

\begin{abstract}
We studied 228 patients, with suspected or confirmed genetic hearing loss, in order to determine the clinical and genetic diagnoses and etiology of each case. Deafness with no associated abnormalities was found in 146 patients (64\%) belonging to 112 families. Syndromic deafness was diagnosed in 82 patients (36\%) belonging to 76 families. The genetic etiology was as follows: autosomal recessive inheritance in $40.8 \%$ of syndromics and non-syndromics, autosomal dominant inheritance in $13.2 \%$ and X-linked recessive in $1.3 \%$. In $44.7 \%$ of the cases, the etiology of the hearing loss could not be determined. Monogenic causes are the most possible etiology in the latter cases. Parental consanguinity was found in $22.4 \%$ of the cases, and deafness was bilateral, profound and neurosensorial in $47.4 \%$ of the patients. An early onset of hearing loss ( $<2$ years of age) occurred in $46.5 \%$ of the cases. These results are similar to previous literature reports.
\end{abstract}

\section{INTRODUCTION}

The incidence of hearing loss varies among populations and, in the developed countries, it is estimated that approximately 1 in 1000 infants have a hearing loss (Fraser, 1964; Feinmesser et al.,1986; Newton, 1989; Steel and Brown, 1994).

Kloenfer et al. (1970) suggested that 46-60\% of the causes of profound deafness are genetic disorders, a claim supported by Nance and McConnell (1974). Konigsmark and Gorlin (1976) estimated that $35-50 \%$ of their cases had a genetic cause, and that in congenital or genetically determined, early-onset deafness, the inheritance was autosomal recessive (AR) in 60-70\% of the cases, autosomal dominant (AD) in 20-30\% and X-linked (XL) in 2\%. Similar findings were reported by Chung and Brown (1970). More recently, Marazita et al. (1993) reported that $47 \%$ of the cases of hearing loss were caused by autosomal recessive inheritance, and $15 \%$ by autosomal dominant inheritance.

Most cases involve isolated hearing loss. Arnos et al. (1992) claimed that $71 \%$ of their cases represented isolated hearing loss (29\% autosomal recessive, $24 \%$ autosomal dominant and $3 \% \mathrm{X}$-linked) with the remaining $29 \%$ being syndromic forms.

The lack of such studies on Brazilian samples and the expressive number of patients with hearing loss referred for investigation in our center prompted us to perform this study in order to determine the genetic diagnoses of each case.

\section{SUBJECTS AND METHODS}

Two hundred and twenty-eight patients from 188 families were studied between 1972 and 1994. Of these, $116(50.9 \%)$ were evaluated between 1989 and 1994 .
Clinical and genetic analysis approaches were done and complementary tests excluded enviromental causes. All patients with a confirmed or suspected genetic cause for the hearing loss were included. All the patients underwent clinical and audiological tests. Patients with no morphological defects and/or neurological deficits were classified as cases of isolated hearing loss whereas the others were classified as cases of associated hearing loss.

Sporadic patients with consanguineous parents or an affected sib were considered as autosomal recessives in the isolated group. An AD or XL pattern of inheritance was established by the patient's pedigree. More than one etiology meant that concurrent factors (genetic and environmental) played a role in the development of hearing loss.

The hearing impairment was classified as described by Northern and Downs (1989), but intermediate groups, such severe-profound, were also considered. Classification as non-coincident meant that the hearing loss was not the same in both ears.

Indirect ophthalmoscopy was done in $39 \%$ of the patients, and $33.8 \%$ underwent computed tomography of the temporal bones.

\section{RESULTS}

The etiological and clinical diagnoses are summarized in Tables I and II.

Consanguinity occurred in $22.4 \%$ of the cases, and in $37.3 \%$ of the families there was recurrence.

The hearing loss was bilateral in $88.6 \%$ of the cases and unilateral in $6.1 \%$. In $5.3 \%$ of the cases, laterality was not informed. Sensorineural hearing impairment accounted for $86 \%$ of the cases, and conductive loss occurred in $3.9 \%$. The hearing loss was mixed in $3.1 \%$ and non-coincident in $2.2 \%$. In $4.8 \%$, the information was absent. The 
Table I - Probable etiological diagnosis of isolated hearing loss among 146 patients of 112 families.

\begin{tabular}{|lrr|}
\hline Etiology & $\mathrm{N}$ & $\%$ \\
\hline Autosomal recessive & 70 & 48.0 \\
Autosomal dominant & 13 & 8.9 \\
X-Linked & 1 & 0.7 \\
Other forms & 6 & 4.1 \\
More than one form & 3 & 2.0 \\
Supposed monogenic & 53 & 36.3 \\
Total & $146^{*}$ & 100 \\
\hline
\end{tabular}

*Corresponds to $64 \%$ of the total number of individuals examined.

Table II - Probable etiological diagnosis of associated hearing loss among 82 patients of 76 families.

\begin{tabular}{|c|c|c|c|}
\hline $\begin{array}{l}\text { Etiology } \\
\text { (inheritance) }\end{array}$ & Diagnosis & $\mathrm{N}$ & $\%$ \\
\hline \multicolumn{4}{|l|}{$\begin{array}{l}\text { Autosomal } \\
\text { recessive }\end{array}$} \\
\hline & Fraser & 1 & 1.2 \\
\hline & Oculocutaneous albinism & 1 & 1.2 \\
\hline & Optico-cochleo-dentate & 1 & 1.2 \\
\hline & External ear anomaly & 3 & 3.7 \\
\hline & Usher & 6 & 7.3 \\
\hline & Jervel-Lange-Nielsen & 1 & 1.2 \\
\hline & $\begin{array}{l}\text { Pigmentary anomaly } \\
\text { and hearing loss }\end{array}$ & 1 & 1.2 \\
\hline & Pendred & 1 & 1.2 \\
\hline & Unknown & 8 & 9.8 \\
\hline \multicolumn{4}{|l|}{ Autosomal } \\
\hline dominant & & 17 & 20.7 \\
\hline & Waardenburg & 5 & 6.1 \\
\hline & Branchio oto & 8 & 9.8 \\
\hline & Treacher-Collins & 2 & 2.4 \\
\hline & Townes-Brocks & 1 & 1.2 \\
\hline & Multiple exostoses & 1 & 1.2 \\
\hline \multirow[t]{3}{*}{$\begin{array}{l}\mathrm{X} \text {-Linked } \\
\text { recessive }\end{array}$} & & 2 & 2.4 \\
\hline & Lesh-Nyhan & 1 & 1.2 \\
\hline & Jubert-Marsidi & 1 & 1.2 \\
\hline Chromosomal & $10 \mathrm{q}-$ & 1 & 1.2 \\
\hline \multicolumn{3}{|l|}{ Etiology } & 47.7 \\
\hline & Goldenhar (OAV spectrum) & 3 & 3.7 \\
\hline & Wildervank & 1 & 1.2 \\
\hline & Pigmentary anomaly & 4 & 4.9 \\
\hline & External ear anomaly & 11 & 13.5 \\
\hline & Klippel-Feil & 1 & 1.2 \\
\hline & Probable syndromes & 19 & 23.2 \\
\hline Total & & $82 *$ & 100 \\
\hline
\end{tabular}

*Corresponds to $36 \%$ of the total number of individual examined.

hearing impairment was profound $(47.4 \%)$, severe-profound $(4.8 \%)$, severe $(11 \%)$, moderate-severe $(4.8 \%)$, moderate $(9.2 \%)$, mild-moderate $(1.7 \%)$, mild $(0.9 \%)$, or non-coincident (13.6\%).

\section{DISCUSSION}

Consanguinity (22.4\%), onset of loss before two years of age $(46.5 \%)$ and profound, bilateral and senso- rineural hearing loss $(47.4 \%)$ were the main general characteristics. The rate of consanguinity was extremely high compared to that of the urban Brazilian population (around 1\%) (Agostini and Meirelles-Nasser, 1986). Parental consanguinity varies widely among deaf children, from $8 \%$ in a Brazilian study (Bento et al., 1986) to $37.6 \%$ in a large study from India (Majumder et al., 1989).

The most common type of hearing loss found in this study, profound, bilateral and sensorineural, agrees with other reports (Salerno et al., 1979; Castro Jr. et al., 1980; Bento et al., 1986; Feinmesser et al., 1986). A profound sensorineural hearing loss accounts for most cases of genetically determined hearing loss (Gorlin et al., 1995).

In a study of over 3,100 patients with hearing loss, Fraser (1976) reported rates of $66 \%$ for AR, $30 \%$ for AD and $4 \%$ for XL inheritance. These figures vary in the other studies (Chung and Brown, 1970; Konigsmark and Gorlin, 1976; Majumder et al., 1989; Reardon, 1990; Marazita et al., 1993). Morton (1991) suggested that $\mathrm{AR}=77 \%$, $\mathrm{AD}$ $=22 \%$ and $\mathrm{XL}=1 \%$. Considering our cases in which the etiology (pattern of inheritance) was determined (126 cases), 93 (73.8\%) were AR, 30 (23.8\%) were AD and 3 $(2.4 \%)$ were XL. These values are within the range reported in the literature. We are unaware of a similar sample group studied in Brazil.

The supposed monogenic cases (Table I) were all physically normal, sporadic patients with no consanguineous parents and had profound, bilateral sensorineural deafness. In these cases, the most probable etiology was autosomal recessive inheritance. Mondini dysplasia and Meniére syndrome were classified as other forms, as described by Gorlin et al. (1995).

Hearing loss of unknown causes occurs in 20-50\% of the cases (Fraser, 1976; Konigsmark and Gorlin, 1976; Ruben et al., 1982; Reardon, 1990; Marazita et al., 1993). In Brazilian patients, hearing loss of undetermined etiology varies from 13.5-38.8\% (Salerno et al., 1979; Castro Jr. et al., 1980; Castagno and Carvalhal, 1985).

In our patients with an unknown etiology and/or clinical diagnosis (33\% or 75 patients out of 228), a genetic cause was supposed. In the group "probable syndromes" (Table II) the patients had dysmorphic signs and represented sporadic cases. Their chromosomal study was normal. In these cases, a monogenic, unknown syndrome must be the explanation.

Ophthalmological evaluation was very important for defining diagnosis of some syndromic cases, such as Usher syndrome. Ophthalmological alterations were the only anomaly associated with hearing loss. The exclusion of certain non-genetic cases helped to define acquired conditions, such as congenital rubella in older patients.

Computed tomography of the temporal bones was also helpful in diagnoses where there were anatomical anomalies. In these cases, a knowledge of the normal dimensions of the tomographic structures of temporal bones in Brazilians is necessary in order to avoid subjective interpretation. 
Our results indicate that a clinical study and delineation of the family history are the main approaches for evaluating hearing loss patients; also, the genetic diagnosis of hearing loss in the Brazilian patients are similar to those referred in the literature.

\section{ACKNOWLEDGMENTS}

The authors thank Prof. Dr. Pedro Luiz Mangabeira Albernaz, Prof. Dr. Manoel de Nóbrega, Prof. Dr. Brasília Maria Chiari and Prof. Dr. Marisa Frasson de Azevedo of the Departamento de Otorrinolaringologia e Distúrbios da Comunicação Humana, Prof. Dr. Hélio Kiitiro Yamashita of the Departamento de Diagnóstico por Imagem and Prof. Dr. Juliana M. Ferraz Sallum of the Departamento de Oftalmologia of the Federal University of São Paulo, EPM, São Paulo, SP. Publication supported by FAPESP.

\section{RESUMO}

Estudamos 228 pacientes, pertencentes a 188 famílias, com deficiência auditiva genética, suspeita ou confirmada, já excluídas causas ambientais, no sentido de determinar o diagnóstico clínico e genético e a etiologia em cada caso, já que estudos deste tipo são escassos em pacientes brasileiros. A surdez sem anomalias associadas compreendeu 146 pacientes (64\%) pertencentes a 112 famílias. Deficiência auditiva sindrômica foi diagnosticada em 82 pacientes $(36 \%)$ pertencentes a 76 famílias. Em 44,7\% deles, não foi possível determinar a etiologia da deficiência auditiva e a origem monogênica foi suposta baseada em dados de freqüência. Com relação ao padrão de herança, $40,8 \%$, entre sindrômicos e não-sindrômicos, foram recessivos, $13,2 \%$ foram dominantes e $1,3 \%$, ligados ao $\mathrm{X}$. Algumas variáveis foram analisadas: consangüinidade parental foi encontrada em $22,4 \%$ dos casos, surdez neurosensorial profunda bilateral em $47,4 \%$, e o início precoce da perda auditiva (até 2 anos) em 46,5\%. O estudo clínico e a história familiar revelaram-se como os principais métodos para a definição diagnóstica. As causas genéticas de surdez em pacientes brasileiros são similares aos estudos referidos na literatura.

\section{REFERENCES}

Agostini, J.M. and Meirelles-Nasser, C. (1986). Consanguineous marriages in the archdiocese of Florianópolis, South Brazil. Rev. Bras. Genet. IX: 479-486.
Arnos, R.S., Cunnigham, M., Israel, J. and Marazita, M.L. (1992). Innovative approach to genetic counseling services for deaf population. Am. J. Med. Genet. 64: 345-351.

Bento, R.F., Silveira, J.A.M., Martucci Junior, O. and Moreira, E. (1986) Etiologia da deficiência auditiva: estudo eletrofisiológico de 136 casos. Folha Med. 93: 359-366.

Castagno, L.A. and Carvalhal, M.L. (1985). Childhood severe-profound sensorineural deafness. Folha Med. 91: 397-400.

Castro Jr., N.P., Lopes F ${ }^{\circ}$., O.C., Figueiredo, M.S. and Redondo, M.C. (1980). Deficiência auditiva infantil: aspectos de incidência, etiologia e avaliação audiológica. Rev. Bras. Otorrinolaringol. 46: 228-236.

Chung, C.S. and Brown, K.S. (1970). Family studies of early childhood deafness ascertained through the "Clarke School for the Deaf". Am. $J$. Hum. Genet. 22: 630-644.

Feinmesser, M., Tell, L. and Levi, H. (1986). Etiology of childhood deafness with reference to group of unknown cause. Audiology 25: 65-69.

Fraser, G.R. (1964). Profound childhood deafness. J. Med. Genet. 1: 118 161

Fraser, G.R. (1976). The Causes of Profound Deafness in Childhood: a Study of 3535 Individuals with Severe Hearing Loss Present at Birth or of Childhood Onset. Johns Hopkins University Press, Baltimore.

Gorlin, R.J., Toriello, H.V. and Cohen Jr., M.M. (1995). Hereditary Hearing Loss and its Syndromes. Oxford University Press, New York.

Kloenfer, H.W., Laguaite, J. and Mclaurin, J.W. (1970). Genetic aspects of congenital hearing loss. Am. Ann. Deaf 115: 17-22.

Konigsmark, B.W. and Gorlin, R.J. (1976). Genetic and Metabolic Deafness. W.B. Saunders, Philadelphia.

Majumder, P.P., Ramesh, A. and Chinnappan, D. (1989). On the genetics of prelingual deafness. Am. J. Hum. Genet. 44: 86-99.

Marazita, M.L., Ploghman, L.M., Rawlings, B., Remington, E., Arnos, K.S. and Nance, W.E. (1993). Genetic epidemiological studies of earlyonset deafness in the U.S. school-age population. Am. J. Med. Genet. 46: 486-491

Morton, N.E. (1991). Genetic epidemiology of hearing loss. Ann. N. Y. Acad. Sci. 630: 16-31.

Nance, W.E. and McConnell, F.E. (1974). Status and progress of research in hereditary deafness. Adv. Hum. Genet. 4: 173-250.

Newton, V.E. (1989). Genetic counseling for isolated hearing loss. $J$. Laryngol. Otol. 103: 12-15.

Northern, J.L. and Downs, M.P. (1989). Audição em Crianças. 3rd edn. Ed. Manole Ltda., São Paulo.

Reardon, W. (1990). Sex linked deafness: Wilde revisited. J. Med. Genet. 27: 376-379.

Ruben, R.J., Levine, R., Baldinger, E., Silver, M., Umano, H., Fishman, G., Feldman, W., Stein, M. and Kruger, B. (1982). Moderate to severe sensorineural hearing impairment child: analysis of etiology, intervention, and outcome. Laryngoscope 92: 38-45.

Salerno, R., Tannuri, V., Stablum, G. and Ceci, M.J. (1979). Avaliação audiométrica de 840 casos de surdez na criança. Rev. Bras. Otorrinolaringol. 45: 208-214.

Steel, K.P. and Brown, S.D.M. (1994). Genes and deafness. Trends Genet 10: 428-435.

(Received December 14, 1998) 
